UDK 577.1 : 61

ISSN 1452-8258

J Med Biochem 41: 316-326, 2022

\title{
MAGNESIUM SUPPLEMENTATION AND IRON STATUS AMONG FEMALE STUDENTS: THE INTERVENTION STUDY
}

\section{SUPLEMENTACIJA MAGNEZIJUMA I STATUS GVOŽĐA KOD STUDENTKINJA: STUDIJA INTERVENCIJE}

\author{
Neda Milinković ${ }^{1}$, Milica Zeković2, Margarita Dodevska3, Brižita Đorđević4, \\ Branimir Radosavljević ${ }^{5}$ Svetlana Ignjatović 1,6, Nevena Ivanović ${ }^{4}$ \\ ${ }^{1}$ University of Belgrade-Faculty of Pharmacy, Department of Medical Biochemistry \\ ${ }^{2}$ Center of Excellence in Research, Nutrition and Metabolism, Institute for Medical Research, \\ National Institute of the Republic of Serbia, University of Belgrade \\ 3 Institute of Public Health of Serbia "Dr Milan Jovanović Batut«, Center for Hygiene and Human Ecology \\ ${ }^{4}$ University of Belgrade-Faculty of Pharmacy, Department of Bromatology \\ ${ }^{5}$ Institute of Chemistry in Medicine, University of Belgrade-Faculty of Medicine \\ ${ }^{6}$ Center for Medical Biochemistry, University Clinical Center of Serbia
}

\section{Summary}

Background: Literature data indicate the benefit of magnesium $(\mathrm{Mg})$ supplementation. The aim of this study was to examine the effect of short-term $\mathrm{Mg}$ supplementation on iron status in healthy female participants.

Methods: One hundred healthy female students of the University of Belgrade - Faculty of Pharmacy participated the study during eleven intervention days. Students ingested $\mathrm{Mg}$ preparations with the same dose of the active substance. The analysis included the measurement of serum iron, unsaturated iron binding capacity (UIBC), total iron binding capacity (TIBC), total $\mathrm{Mg}(\mathrm{t} M \mathrm{~g})$, ionized $\mathrm{Mg}$ (iMg), complete blood count, met-, carboxy- and oxy-haemoglobin (metHgb, $\mathrm{COHgb}, \mathrm{O}_{2} \mathrm{Hgb}$ ). Transferrin concentrations and percentage of transferrin saturation (SAT) were calculated manually. The association among the analyzed biochemical parameters was examined using polynomial regression. A principal component analysis (PCA) was used for the evaluation of interdependence between the analyzed parameters.

Results: A statistically significant trend for change in $\mathrm{O}_{2} \mathrm{Hgb}$ (\%) by tertiles of iMg concentrations was found $(P=0.029)$. Serum $\mathrm{tMg}$ reached significant positive correlation with the SAT at concentration levels greater than $0.9 \mathrm{mmol} / \mathrm{L}$, after 11 days of intervention $\left(R^{2}=0.116\right)$. lonized $M g$ in a concentration higher than $0.6 \mathrm{mmol} / \mathrm{L}$ is positively correlated with SAT and serum Fe $\left(R^{2}=0.214 ; 0.199\right.$, respectively).

\section{Kratak sadržaj}

Uvod: Literaturni podaci ukazuju na benefit suplementacije magnezijumom (Mg). Cilj ove studije bio je da se ispita uticaj kratkotrajne suplementacije Mg na status gvožđa kod zdravih žena.

Metode: Sto zdravih studentkinja Univerzitet u Beogradu Farmaceutskog fakulteta je učestvovalo $u$ istraživanju tokom jedanaest dana intervencije. Studenti su uzimali preparate $\mathrm{Mg}$ sa istom dozom aktivne supstance. U serumu je određivano gvožđe, nezasićen kapacitet vezivanja gvožđa (UIBC), ukupan kapacitet vezivanja grožđa (TIBC), ukupan $M g(t M g)$, jonizovni $M g$ (iMg), kompletna krvna slika, met-, karboksi- ioksi- hemoglobin (metHgb, $\mathrm{COHgb}, \mathrm{O}_{2} \mathrm{Hgb}$ ). Transferin i saturacija transferina (SAT) su izračunati ručno. Povezanost analiziranih biohemijskih parametara je ispitana pomoću polinomalne regresije. Za procenu međuzavisnosti između analiziranih parametara korišćena je analiza glavnih komponenti (PCA).

Rezultati: Utvrđen je statistički značajan trend promene $\mathrm{O}_{2} \mathrm{Hgb}(\%)$ po tertilima koncentracija iMg ( $\left.\mathrm{P}=0,029\right)$. Ukupan $\mathrm{Mg}$ je dostigao značajnu pozitivnu korelaciju sa SAT pri koncentracijama većim od 0,9 mmol/L, nakon 11 dana intervencije $\left(R^{2}=0,116\right)$. Jonizovani $M g$ u koncentraciji većoj od $0,6 \mathrm{mmol} / \mathrm{L}$ pozitivno korelira sa SAT i grožđem $\left(\mathrm{R}^{2}\right.$ $=0,214 ; 0,199$, redom). PCA analizom je pokazana varijabilnost od $64,7 \%$ za dve ose nakon 11 dana.

Address for correspondence:

Neda Milinković

Vojvode Stepe 450, 11121 Beograd, Srbija

064-422-3685

e-mail: nedan@pharmacy.bg.ac.rs 
PCA revealed variability of $64.7 \%$ for two axes after 11 days. Conclusions: $\mathrm{Mg}$ supplementation leads to an improvement in the certain iron status parameters even in individuals with optimal levels of these indices. However, caution should be exercised when supplementing $\mathrm{Mg}$, and laboratory monitoring of the interaction is required.

Keywords: magnesium, supplementation, iron status, female, students

\section{Introduction}

Magnesium $(\mathrm{Mg})$ plays an important role in many physiological functions. As a cofactor for over 600 enzymes and an activator of an additional 200 enzymes, $\mathrm{Mg}$ is involved in almost all major biochemical and metabolic processes in the body. Magnesium has an important role in macronutrient and energy metabolism, neuromuscular function, bone development, cell proliferation and signalling pathways $(1,2)$. Magnesium is an essential micronutrient, and therefore it must be supplied regularly via food sources to reach the recommended intake and prevent deficiency. Insufficient dietary intake of $\mathrm{Mg}$ is one of the most important causes of hypomagnesaemia (3). Recommendations for $\mathrm{Mg}$ intake for adults in the United States (Recommended Daily Allowances, RDA) are $320 \mathrm{mg} /$ day for women and $420 \mathrm{mg} /$ day for men and in Europe $300 \mathrm{mg} /$ day for women and 350 $\mathrm{mg} /$ day for men (Dietary Reference Values, DRVs) (4, 5). Although $\mathrm{Mg}$ is widely distributed in plant and animal foods as well as in beverages, literature data indicate that the dietary intake of $\mathrm{Mg}$ is below the recommended levels in a large percentage of European and US populations where there is a higher prevalence of the Western dietary pattern (6-9). There is also evidence that many young women in various European countries and in the US fail to achieve these recommended intakes $(2,10)$. Furthermore, epidemiological studies have shown that people who follow a Western-style diet, characterized by a high intake of processed foods, have an inadequate intake of several micronutrients, with dietary $\mathrm{Mg}$ intake of less than $30-50 \%$ of RDA $(11,12)$.

In recent decades, insufficient $\mathrm{Mg}$ intake and consequent hypomagnesaemia have been associated with several cardiovascular conditions, including hypertension, an increased risk of glucose intolerance, metabolic syndrome, and type 2 diabetes (1-3, 13). Moreover, a meta-analysis of eight prospective cohort studies has reported a significant inverse association between $\mathrm{Mg}$ intake and risk of type 2 diabetes in a dose-response manner (14). In addition, $\mathrm{Mg}$ deficiency is closely related to the development of anaemia $(15,16)$.

There is accumulating research regarding the importance and modalities for achieving adequate $\mathrm{Mg}$ intake. Magnesium supplementation may be a good strategy for preventing deficiency and prevent-
Zaključak: Suplementacija Mg dovodi do poboljšanja određenih parametara statusa gvožđa čak i kod pojedinaca sa optimalnim nivoima ovih parametara. Međutim treba biti oprezan pri suplementaciji $\mathrm{Mg}$, a dodatno je neophodno i laboratorijsko praćenje ovih interakcija.

Ključne reči: magnezijum, suplementacija, status gvožđa, žene, studenti

ing associated diseases, when the recommended daily intake cannot be provided solely by the diet (1$3,13)$. According to the recently conducted survey, $\mathrm{Mg}$ supplements were among ten most popular dietary supplements used in adult population (17). Magnesium supplementation led to improved anemia in thalassemic mice and improved erythrocyte membrane transport abnormalities in patients with sickle cell disease $(18,19)$, while in athletes, $M g$ supplementation increased erythrocyte count and haemoglobin levels (20). Moreover, according to the Shi et al. (16) Mg supplementation may be a safer alternative than iron ( $\mathrm{Fe}$ ) supplementation in the prevention of anemia.

Although previously published data suggest the beneficial effects of increased $\mathrm{Mg}$ intake on Fe status among anaemic individuals, research on this issue is lacking for the non-anaemic population $(15,16)$. It is generally accepted that the female population is more prone to Fe deficiency anemia and more vulnerable on Fe status than men $(21,22)$. Therefore, it is important to ensure stable Fe status, particularly in the reproductive period of life. The aim of this study was to examine the effect of short-term $\mathrm{Mg}$ supplementation in doses of $375 \mathrm{mg}$ corresponding to the $100 \%$ of Mg Nutritive Referent Value NRV on Fe status in healthy female participants.

\section{Materials and Methods}

\section{Ethics statement}

This study was conducted following the guidelines laid down in the Declaration of Helsinki and the study protocols were approved by the Ethics Commission of the University of Belgrade - Faculty of Pharmacy, Belgrade, Serbia (approval number: $188 / 2,2020$ ). All subjects went through verbal and written consent processes.

\section{Study design and subjects}

One hundred healthy female students of the University of Belgrade - Faculty of Pharmacy agreed to participate in this study. Eligible students were approached in the Faculty setting. Recruitment brochure contained detailed information regarding the purpose of the study, procedures involved as well 
as rights and expectations of the potential participants. The main inclusion criteria were: age between 18 and 30 years, body mass index (BMI) between 18.5 and $29.9 \mathrm{~kg} / \mathrm{m}^{2}$ and willingness to maintain regular dietary habits throughout the study. The study did not include students who had altered Fe status (primarily based on complete blood count analysis), who had taken $\mathrm{Mg}$ supplements over the previous three months, or students who had confirmed chronic kidney and/or gastrointestinal tract disease. Finally, after applying the exclusion criteria, 46 respondents remained in the analytical sample.

Anthropometric parameters were measured at the beginning of the study. Height was measured to the nearest $0.1 \mathrm{~cm}$ (Perspective Enterprises, Kalamazoo, MI, USA). Body weight and body fat percentage were determined using the bioimpedance method (BC-418MA, Tanita, USA). Body Mass Index (BMI) was calculated as weight $(\mathrm{kg}) /$ height $^{2}\left(\mathrm{~m}^{2}\right)$.

During eleven intervention days, students ingested $\mathrm{Mg}$ preparations (citrate, oxide and carbonate) with the same dose of the active substance (375 $\mathrm{mg} /$ day). The subjects were randomly assigned to three groups according to the form of the $\mathrm{Mg}$ preparation.

\section{Dietary intake assessment}

Dietary intake data was collected via participants' subjective retrospective reports in two study points. Participants were administered $24 \mathrm{~h}$ dietary recalls on two consecutive days before the initiation of the supplementation ( $\mathrm{t} 0$ ) and after 11 days of using the provided $\mathrm{Mg}$ supplements, within the follow-up assessment $(t 2)$. Dietary information and relevant contextual data were obtained over the course of face-to-face structured interviews led by a trained researcher. In order to improve the accuracy of the report, enhance participants' memory, and assure the provision of detailed descriptions of consumed items multiple-pass methodological approach was applied. To assist respondents in portion size quantification interviewers used validated, 135-item Food Atlas featuring coloured photographs of increasing portion sizes for a selection of Balkan region-specific simple foods and composite dishes (23). Additionally, subjects reported quantities of foods consumed based on standardized household measures, natural units and labelling information for packaged products. Diet Assess \& Plan - original software-based platform for comprehensive nutritional assessment was applied in questionnaire processing (24). Subsequent conversion of food consumption information into energy and nutrient intake estimates was performed according to data compiled in National Serbian Food Composition Database (25). Age and gender-adjusted nutritional recommendations proposed by EFSA i.e., Dietary Reference Values (DRVs) were applied for micronutrient adequacy evaluation (26).

\section{Biochemical assessment}

Serum biochemical parameters were analyzed before the initiation of the intervention, at baseline $(t 0)$, on the fifth day (t1) and the eleventh day $(t 2)$ of the intervention period. Blood samples were collected by professional phlebotomists via venipuncture between 7:00 am and 9:00 am. All studied participants were donated blood samples after the $12 \mathrm{~h}$ of overnight fast. Standard operating procedures for blood collection and sample preparation were followed (27). A closed venipuncture system, Beckton Dickinson (BD) 22 Standard Wire Gauge (SWG), a reusable adapter and vacutainers were used. Vacutainers with clot activator (BD Vacutainer ${ }^{\circledR} S S T^{\mathrm{TM}}$ Tubes) were used to obtain serum samples. Serum samples were used for measurement of serum Fe, unsaturated iron binding capacity (UIBC), total iron binding capacity (TIBC) and total $\mathrm{Mg}$ ( $\mathrm{t} M \mathrm{Mg})$. Transferrin concentrations and percentage of transferrin saturation (SAT) were calculated according to the formula proposed by Dacie et al. (28). Complete blood count was determined using the whole blood samples collected in a tube with liquid anticoagulant (ethylenediaminetetraacetic acid, EDTA) (BD Vacutainer ${ }^{\circledR}$ EDTA Tubes). For the analyses of met-, carboxy- and oxy-haemoglobin (metHgb, COHgb, $\mathrm{O}_{2} \mathrm{Hgb}$ ) and ionized $\mathrm{Mg}(\mathrm{iMg})$, lithium-heparin spraycoated tube (BD Vacutainer ${ }^{\circledR}$ Heparin Tubes) were used. Serum Fe, UIBC, TIBC and tMg concentrations were measured using the spectrophotometric method with commercial reagents, on Olympus AU400 biochemical analyzer (Beckman Coulter, Inc., California, USA). Complete blood count was measured in whole blood samples using electrical impedance on Coulter Ac•T diff Hematology Analyzer (Beckman Coulter, Inc., California, USA). Total haemoglobin (tHgb) concentrations were measured by spectrophotometry on Coulter Ac・T diff Hematology Analyzer. MetHgb, $\mathrm{COHgb}, \mathrm{O}_{2} \mathrm{Hgb}$ and $\mathrm{iMg}$ were determined approximately up to 60 min after collection using Stat Profile Prime Plus Critical Care blood gas analyzer (Nova Biomedical, USA). The precision and accuracy of the methods were verified using commercial control samples for all the listed parameters.

\section{Statistical analysis}

The normality of the data distribution was analysed using the One-sample Kolmogorov-Smirnov test. Normally distributed data were presented as mean and standard deviation (SD). Non-normally distributed data were presented as a median and interquartile range (IQR), by subtracting the first from the third quartile of the distribution. For data that were not normally distributed, values were log-trans- 
formed before analysis. Linear regression analysis was performed to evaluate the relationship between investigated parameters. The association among serum $\mathrm{Fe}$ and $\mathrm{Mg}$ (as $\mathrm{tMg}, \mathrm{i} \mathrm{Mg}$ and $\mathrm{i} \mathrm{Mg} / \mathrm{t} \mathrm{Mg}$ ) with certain (some) biochemical parameters was presented as polynomial regression. A principal component analysis (PCA) was used for the evaluation of interdependence between serum $\mathrm{Fe}$ and $\mathrm{Mg}$ (as $\mathrm{tMg}$, iMg and $\mathrm{i} \mathrm{Mg} / \mathrm{t} \mathrm{Mg}$ ) and biochemical parameters (UIBC, TIBC, Transferrin, $\mathrm{tHgb}$, hematocrit, SAT and Fe). We have considered $\mathrm{p}$-value $<0.05$ as statistically significant. All statistical analyses were performed using IBM SPSS version 24 (SPSS Inc., USA).

\section{Results}

Baseline participants' characteristics are presented in Table I. Participants were on average 23 years old, with a BMI of $21.8 \mathrm{~kg} / \mathrm{m}^{2}$. Erythrocyte indices and biochemical parameters indicated a favourable Fe status. All presented parameters were within the reference values routinely used in the laboratory, and recommended by the test manufacturer. Given that the aim of this study was to examine the effect of the applied dose of magnesium of $375 \mathrm{mg}$, in which magnesium is most often found in dietary supplements on the Serbian market (dose that meets $100 \%$ nutritional reference value for $\mathrm{Mg}$ ), data was further analysed without partition of subjects into sub cohorts in relation to different types of supplemented magnesium (citrate, oxide and carbonate).

Estimated daily energy and nutrient intakes are presented in Table II. Based on the average of dietary recalls for two consecutive days at baseline evaluation (t0) and after 11 days ( $\mathrm{t} 2$ ) of using provided dietary supplements, the results obtained indicate that food intake did not change over time.

Estimated intake levels of eight food groups and their corresponding contributions to daily iron intake based on repeated $24 \mathrm{~h}$ dietary recalls are presented in Table III. Dominant Fe dietary sources were grains and cereal products $(28.6 \%)$, meat and meat products $(22.3 \%)$ and vegetables and vegetable products (15.7\%).

A statistically significant trend for change in $\mathrm{O}_{2} \mathrm{Hgb}(\%)$ by tertiles of whole blood iMg concentrations was found. With the increase of $\mathrm{iMg}$, the percentage of $\mathrm{O}_{2} \mathrm{Hgb}$ decreases. Additionally, we found a significant increase in changes of SAT (\%) by quartile until the third quartile of $\mathrm{tMg}$ values. Interestingly, in the fourth quartile of serum $\mathrm{tMg}$ values, a significant decrease in SAT (\%) was observed.

Based on polynomial regression analyses, serum tMg reached significant positive correlation with the SAT at concentration levels greater than $0.9 \mathrm{mmol} / \mathrm{L}$, after 11 days of supplementary intervention $\left(R^{2}=0.116\right.$; Figure $\left.1 B\right)$. Before the intervention, there
Table I Baseline participant characteristics $(N=46)$.

\begin{tabular}{|c|c|}
\hline Parameters & Mean $\pm \mathrm{SD}^{\mathrm{a}}$ Median $(\mathrm{IQR})^{\mathrm{b}}$ \\
\hline Age, years & $23(2)$ \\
\hline $\mathrm{BMI}, \mathrm{kg} / \mathrm{m}^{2}$ & $21.8(2.8)$ \\
\hline Total body fat, $\%$ & $25.49 \pm 4.85$ \\
\hline Systolic pressure $(\mathrm{mmHg})$ & $113.8 \pm 10.6$ \\
\hline Diastolic pressure $(\mathrm{mmHg})$ & $80.3 \pm 8.6$ \\
\hline WBC, $10^{9} / \mathrm{L}$ & $7.29 \pm 1.13$ \\
\hline Lymphocytes, \% & $33.5 \pm 5.7$ \\
\hline Monocytes, \% & $6.0 \pm 1.6$ \\
\hline Granulocytes, \% & $60.4 \pm 5.9$ \\
\hline Lymphocytes, \# & $2.4 \pm 0.5$ \\
\hline Monocytes, \# & $0.4(0.1)$ \\
\hline Granulocytes, \# & $4.4 \pm 0.9$ \\
\hline $\mathrm{RBC}, 10^{12} / \mathrm{L}$ & $4.51 \pm 0.28$ \\
\hline $\mathrm{tHgb}, \mathrm{g} / \mathrm{L}$ & $140(4)$ \\
\hline Hct, L/L & $0.439 \pm 0.029$ \\
\hline$M C V, f L$ & $89.6 \pm 4.2$ \\
\hline $\mathrm{MCH}, \mathrm{pg}$ & $29.9 \pm 1.7$ \\
\hline $\mathrm{MCHC}, \mathrm{g} / \mathrm{L}$ & $334 \pm 7$ \\
\hline RDW, \% & $14.5 \pm 1.7$ \\
\hline $\mathrm{iMg}, \mathrm{mmol} / \mathrm{L}$ & $0.59 \pm 0.032$ \\
\hline $\mathrm{tMg}, \mathrm{mmol} / \mathrm{L}$ & $0.89 \pm 0.054$ \\
\hline $\mathrm{Fe}, \mu \mathrm{mol} / \mathrm{L}$ & $14.89 \pm 5.65$ \\
\hline UIBC, $\mu \mathrm{mol} / \mathrm{L}$ & $51.8 \pm 13.8$ \\
\hline TIBC, $\mu \mathrm{mol} / \mathrm{L}$ & $66.7 \pm 12.5$ \\
\hline SAT, $\%$ & $23.9 \pm 9.8$ \\
\hline Transferrin, g/L & $2.6(0.7)$ \\
\hline MetHgb, \% & $0.4(0.15)$ \\
\hline $\mathrm{COHgb}, \%$ & $3.66 \pm 2.02$ \\
\hline $\mathrm{O}_{2} \mathrm{Hgb}, \%$ & $40.6 \pm 19.7$ \\
\hline
\end{tabular}

${ }^{a}$ Mean $\pm S D$, the standard deviation for normal distribution

${ }^{b}$ Median (IQR); IQR, interquartile range (quartile3-quartile1) for not normally distribution

WBC, white blood cells (Leucocytes); RBC, red blood cells; $\mathrm{HHgb}$, haemoglobin; Hct, hematocrit; MCV, mean cell volume; $M C H$, mean haemoglobin concentration; $\mathrm{MCHC}$, amount of haemoglobin per unit volume in a single red blood cell; Fe, iron; UIBC, unsaturated iron-binding capacity; TIBC, total iron-binding capacity; SAT, total transferrin saturation

was no statistically significant correlation between serum $\mathrm{t} M g$ and SAT (Figure $1 \mathrm{~A}$ ). lonized $\mathrm{Mg}$ in a concentration higher than $0.6 \mathrm{mmol} / \mathrm{L}$ is positively correlated with SAT and serum Fe $\left(R^{2}=0.214 ; 0.199\right.$, respectively; Figure $2 B$ ) after supplementation, which was not the case before the supplementation, because at the mentioned concentration the serum $\mathrm{Fe}$ decreased slightly (Figure 2A). 
Table II Daily energy and nutrient intakes among study participants assessed by the average of dietary recalls for two consecutive days at baseline evaluation ( $\mathrm{t} 0$ ) and after 11 days ( 2 ) of using provided dietary supplements.

\begin{tabular}{|l|c|c|c|}
\hline \multicolumn{4}{|c|}{ Intervention Group (N=46) } \\
\hline Energy/Nutrients & t0 & t2 & P \\
\hline Energy (kcal) & $1733.6 \pm 550.6$ & $1804.9 \pm 485.6$ & 0.501 \\
\hline Carbohydrates (TEl\%) & $29.9 \pm 9.8$ & $28.6 \pm 7.8$ & 0.066 \\
\hline Proteins (\%TEI) & $10.5 \pm 3.9$ & $11.7 \pm 3.3$ & 0.283 \\
\hline Fats (\%TEI) & $29.0 \pm 13.1$ & $31.9 \pm 13.1$ & 0.177 \\
\hline Fe (mg) & $7.8 \pm 3.3$ & $8.6 \pm 3.0$ & 0.741 \\
\hline Mg $(\mathrm{mg})$ & $236.2 \pm 85.1$ & $230.8 \pm 74.1$ & 0.052 \\
\hline Zn $(\mathrm{mg})$ & $7.3 \pm 3.3$ & $8.4 \pm 3.2$ & 0.269 \\
\hline Folic acid $(\mu \mathrm{g})$ & $189.2 \pm 96.6$ & $210.9 \pm 78.2$ & 0.053 \\
\hline Vitamin B12 $(\mu \mathrm{g})$ & $2.5 \pm 1.3$ & $2.6 \pm 1.2$ & 0.631 \\
\hline Vitamin C $(\mathrm{mg})$ & $61.5 \pm 7.3$ & $68.9 \pm 6.0$ & 10.0 \\
\hline
\end{tabular}

\%TEI, percentage of total energy intake; $\mathrm{p}<0.05$ - statistically significant difference between $\mathrm{t} 0$ and $\mathrm{t} 2$ within the same intervention group.

Mean $\pm S D$, the standard deviation for normal distribution

Table III Daily intake levels presented as the median levels and 5th and 95th percentiles of eight food groups and their corresponding contributions to daily iron intake based on repeated $24 \mathrm{~h}$ dietary recalls among study participants.

\begin{tabular}{|l|c|c|c|c|c|}
\hline \multirow{2}{*}{ Food groups } & \multicolumn{2}{|c|}{$\begin{array}{c}\text { Intake of the food group } \\
\text { (mg/day) }\end{array}$} & \multicolumn{2}{c|}{$\begin{array}{c}\text { The average contribution } \\
\text { to the total iron intake } \\
(10.52 \text { mg/day) }\end{array}$} \\
\hline & Median & $\begin{array}{c}5 \text { th } \\
\text { percentile }\end{array}$ & $\begin{array}{c}95 \text { th } \\
\text { percentile }\end{array}$ & $\begin{array}{c}\text { Iron intake } \\
\text { (mg/day) }\end{array}$ \\
\hline Milk and dairy products & 0.18 & 0.01 & 0.44 & 2.25 & 0.24 \\
\hline Eggs and egg products & 0.63 & 0.15 & 3.34 & 8.01 & 0.84 \\
\hline Meat and meat products & 1.64 & 0.38 & 5.92 & 22.28 & 2.34 \\
\hline Grains and cereal products & 2.28 & 0.71 & 5.60 & 28.57 & 3.00 \\
\hline Nuts and seeds & 0.42 & 0.03 & 2.24 & 6.94 & 0.73 \\
\hline Vegetables and vegetable products & 1.29 & 0.14 & 4.03 & 15.67 & 1.65 \\
\hline Fruit and fruit products & 0.51 & 0.04 & 1.54 & 4.84 & 0.51 \\
\hline Sugar and confectionary products & 0.21 & 0.01 & 1.95 & 4.37 & 0.46 \\
\hline
\end{tabular}

Table IV Associations between estimated $\mathrm{O}_{2} \mathrm{Hgb}$ and tertiles of whole blood ionized $\mathrm{Mg}$ at the eleventh day.

\begin{tabular}{|l|c|c|c|c|}
\hline \multirow{2}{*}{$\begin{array}{l}\text { Biochemical } \\
\text { parameter }\end{array}$} & \multicolumn{4}{|c|}{ Whole blood ionized Mg on the eleventh day } \\
\cline { 2 - 5 } & $\begin{array}{c}\mathrm{T} 1(\mathrm{~N}=17) \\
<0.59\end{array}$ & $\begin{array}{c}\mathrm{T} 2(\mathrm{~N}=16) \\
0.60-0.63\end{array}$ & $\begin{array}{c}\mathrm{T3}(\mathrm{N}=13) \\
0.64-0.68\end{array}$ & P for trend \\
\hline $\mathrm{O}_{2} \mathrm{Hgb}(\%)$ & $\begin{array}{c}49.9 \\
(38.7-61.1)\end{array}$ & $\begin{array}{c}41.3 \\
(29.4-53.2)\end{array}$ & $(20.9-33.7)$ & 0.029 \\
\hline
\end{tabular}

$\mathrm{p}<0.05$ - a statistically significant difference for trend

$\mathrm{T}$, tertil; $\mathrm{O}_{2} \mathrm{Hgb}$, oxy-haemoglobin; $\mathrm{N}$, number of participants 

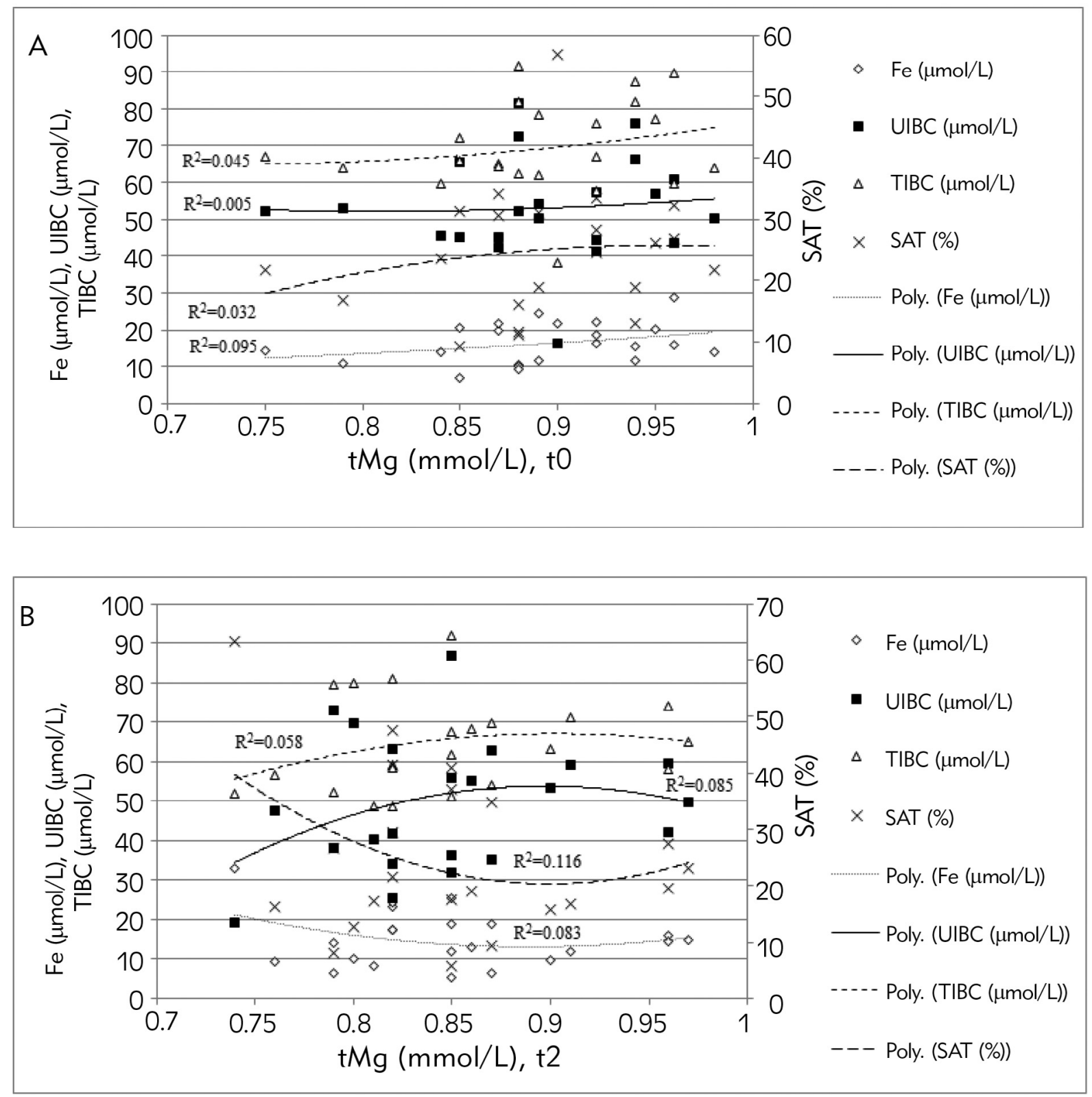

Figure 1 Interdependence between serum total magnesium (tMg) with serum iron (Fe), unsaturated iron binding capacity (UIBC), total iron binding capacity (TIBC) and transferrin saturation (SAT) at the beginning (A) and after 11 days (B) of supplementary intervention.

PCA was applied to integrate results of biochemical parameters, to discover the possible correlations among measured parameters, and to classify the parameters in a factor plane. PCA is a factor model in which the factors are based on summarizing the total variance. The first two factors should correspond to a high \% of the variance to ensure that the maps based on the first two factors are a good quality projection of the initial multi-dimensional table. At the beginning of the experiment, PCA revealed that two axes participated in total variability with $55.8 \%$ (F1: $34.6 \%$ and $F 2: 21.2 \%$ ), and after 11 days, the axes participated in total variability with $64.7 \%$ (F1: 46.7\% and F2: 18.0\%). According to the PCA, Transferrin, TIBC, UIBC, SAT, iMg/tMg and iMg correlated mainly with the first axis - factor $(0.952$; $0.952 ; 0.940 ;-0.607 ;-0.579$ and -0.520 , respectively), while serum $\mathrm{Fe}$, tHgb, SAT, Mg; hematocrit; $\mathrm{iMg} / \mathrm{tMg}$, and MetHgb were mainly connected to the second axis - factor $(0.758 ; 0.721 ; 0.588 ; 0.442$; 

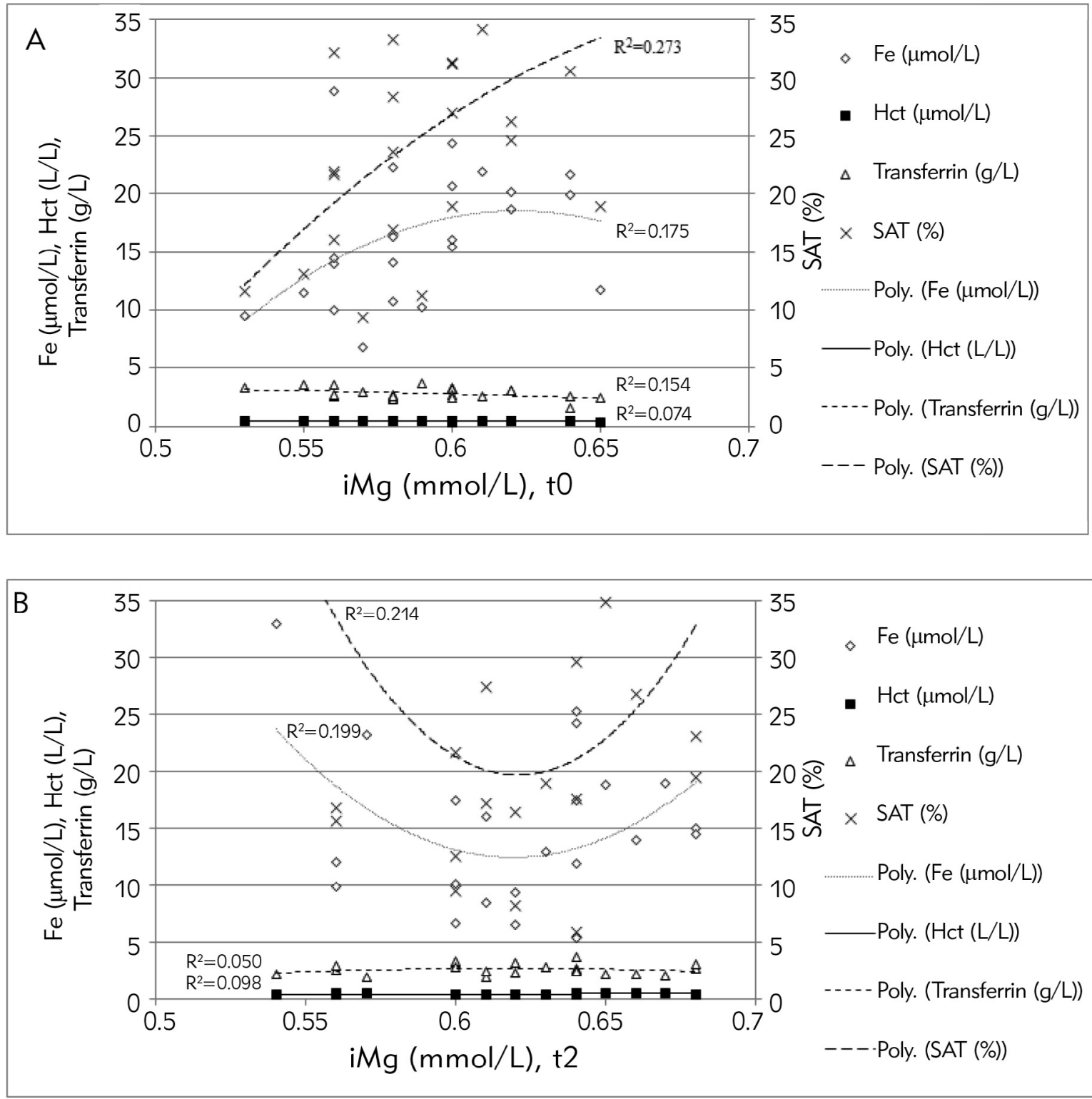

Figure 2 Interdependence between serum ionized magnesium (iMg) with serum iron (Fe), hematocrit (Hct), transferrin and transferrin saturation (SAT) at the beginning (A) and after 11 days (B) of supplementary intervention.

$0.317 ;-0.554 ;-0.510$; respectively), Figure $4 A$. In the first factor (F1) there is a strong positive correlation between TIBC, UIBC and Transferrin, while SAT, $\mathrm{i} \mathrm{Mg} / \mathrm{tMg}$ and $\mathrm{i} \mathrm{Mg}$ are negatively correlated. The second factor (F2) is positively correlated with serum $\mathrm{Fe}, \mathrm{HHgb}, \mathrm{SAT}$, serum $\mathrm{Mg}$; hematocrit, and negatively with $\mathrm{iMg} / \mathrm{tMg}$, and MetHgb. After 11 days of the study, F1 was determined with UIBC, TIBC, Transferrin; SAT; serum $\mathrm{Fe}$; $\mathrm{tHgb}$ and hematocrit $(-0.982$,
$-0.890,-0.890,0.890,0.822,0.777$, and 0.698 , respectively), whereas F2 was determined with $\mathrm{iMg} / \mathrm{tMg}$; iMg and serum $\mathrm{Mg}(0.981 ; 0.720$ and 0.616 ; respectively), Figure $4 B$. The first factor (F1) is positively correlated with SAT; serum $\mathrm{Fe}$; $\mathrm{tHgb}$ and hematocrit, and negatively with UIBC, TIBC and Transferrin, while second factor (F2) is positively correlated with $\mathrm{iMg} / \mathrm{t} \mathrm{Mg}$ and $\mathrm{i} M g$, and negatively with serum $\mathrm{tMg}$. 

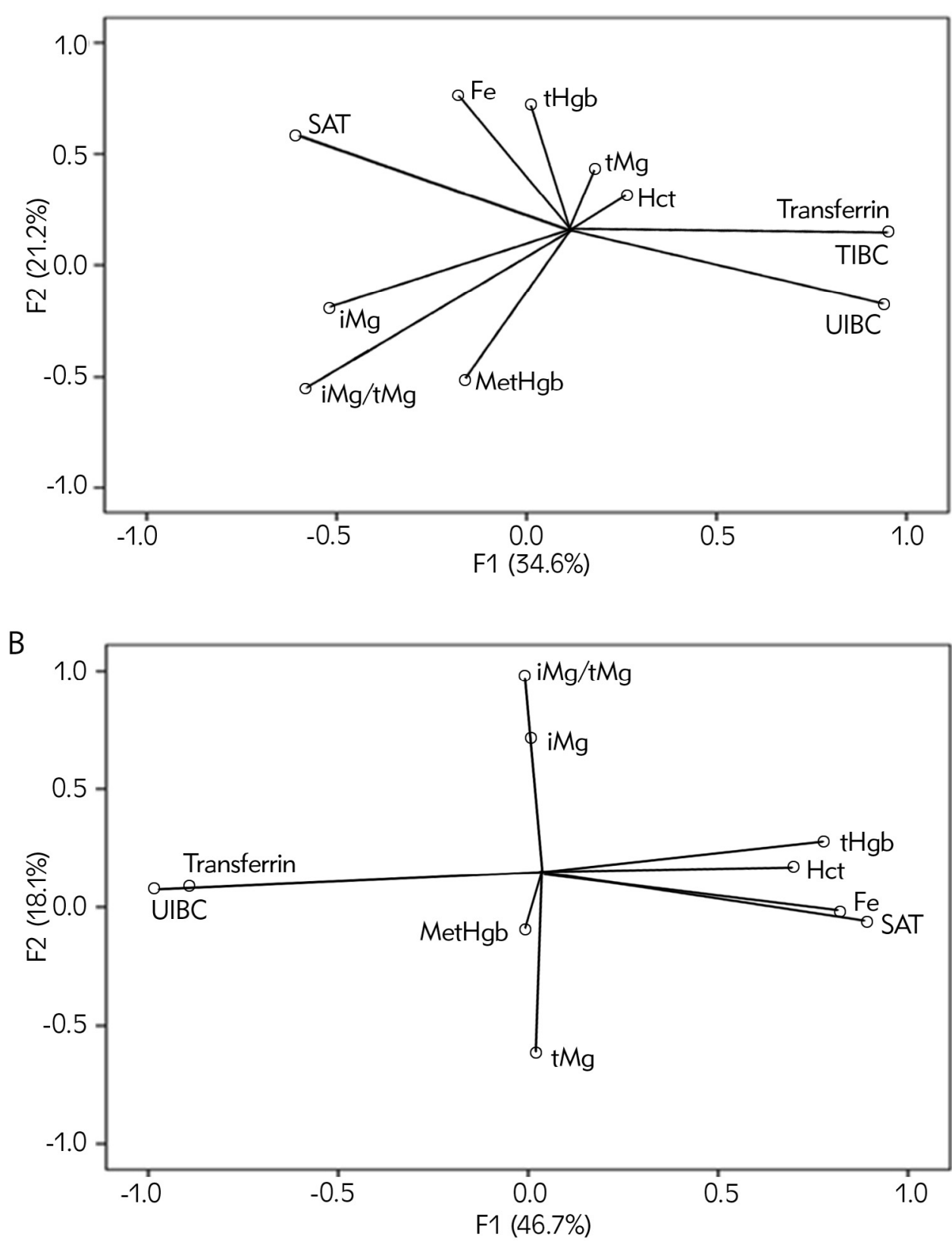

Figure 3 Principal Component Analysis for serum iron (Fe) and serum magnesum ( $\mathrm{Mg}$ ) (as total (tMg), ionized (iMg) and $\mathrm{i} \mathrm{Mg} / \mathrm{Mg}$ ) and biochemical parameters (unsaturated iron binding capacity (UIBC), total iron binding capacity (TIBC), transferrin, transferrin saturation (SAT), total haemoglobin ( $\mathrm{tHgb})$, MetHgb and hematocrit $(\mathrm{Hct})$ ) content at the beginning ( $\mathrm{A}$, $\mathrm{t} 0)$ and after 11 days $(B, t 2)$ of supplementary intervention.

\section{Discussion}

To the best of our knowledge this is the first study examining the short-term effects of $\mathrm{Mg}$ supplementation in daily doses corresponding to $100 \%$ NRV on Fe status in young healthy women. Intervention study was conducted among young female subjects with an aim to explore the effects of short-term $\mathrm{Mg}$ supplementation on indices of iron status. Namely, the literature data indicate that the human body adapts to the additional intake of magnesium, calcium and phosphorus in the period from 7 to 10 days and that the mineral balance is achieved in the period of a few days after supplementation intake (29). After 11 days of supplementation in a dose corresponding to $\mathrm{Mg}$ DRV (i.e. $375 \mathrm{mg}$ ), direct association was found between the serum $\mathrm{tMg}$ concentration and SAT. Furthermore, whole blood iMg correlated positively with SAT and serum Fe. These observations 
were also confirmed by polynomial regression. These finding suggest that $\mathrm{Mg}$ supplementation and increased $\mathrm{Mg}$ levels, both serum $\mathrm{tMg}$ and blood $\mathrm{iMg}$, might exert beneficial impact on obtaining favorable Fe status among young female population.

In this sample, the average iron intake was significantelly bellow the DRI and DRV for women, i.e., $18 \mathrm{mg} /$ day and $16 \mathrm{mg} /$ day, respectively $(4,5)$. These findings are consistent with the results of other studies which reported dietary iron intake in women of reproductive age in Europe $(30,31)$. Regardless the suboptimal dietary intake of $\mathrm{Fe}$, biomarkers of Fe status were within the normal range. This can be explained by the following facts: iron metabolism was primarily regulated at the level of absorption, and the examined population did not have gastrointestinal disorders. Also, the amount of iron that enters the body from food is regulated by the body's need for iron. Other studies also indicate that a significant proportion of the UK population has Fe intake below recommendations and a low prevalence of poor Fe status (32-34). This might be because there are important uncertainties in the DRVs for Fe intake which may be too high, particularly for girls and women of reproductive age. It is recommended that the DRVs for iron should be reviewed when more data becomes available. Good quality dose-response data are required to enable a reassessment of the DRVs for iron. Knowledge of the systemic regulation and mediation of iron homeostasis should be applied to characterize better the responses to increased and reduced systemic needs for $\mathrm{Fe}$ and development, or better validation, of existing markers used to assess the adequacy of Fe status in populations and individuals. The main food sources of Fe among participants in our study were grains and cereal products with contribution of more than a quarter of total dietary intake of this nutrient followed by meat and meat products and vegetables. These three food groups together contributed to $65 \%$ of estimated iron intake in the participants. These observations are in accordance with previously published data for European population $(35,36)$. Furthermore, dietary intake assessment revealed that $\mathrm{Mg}$ intake among female student population were also below the recommended level although mean baseline $\mathrm{tMg}$ concentration was adequate.

There is a lack of literature data regarding the effect of increased $\mathrm{Mg}$ intake on Fe status in young women in the reproductive period. This issue needs to be addressed taking into account that $\mathrm{Mg}$ supplements are one of the most popular dietary supplements used in adult population (17) and the fact that anemia is most prevalent among females of childbearing age (36).

In this study, we tried to explore the connection between serum $\mathrm{Fe}$ and serum $\mathrm{Mg}$ (as $\mathrm{t} \mathrm{Mg}$, iMg and $\mathrm{i} \mathrm{Mg} / \mathrm{Mg}$ ) and other biochemical indices of Fe status using the PCA approach, before and after Mg supplementation. Given that the diet did not change over intervention period intake of $\mathrm{Mg}$ and $\mathrm{Fe}$ were not considered in PCA. At the beginning of the study, before the initiation of the supplementation, there was a strong positive correlation between UIBC, TIBC and transferrin, but after 11 days of supplementation we found a strong negative correlation among the same analyzed parameters. Analyses revealed that even in a short period of intervention there is a noticeable effect of $\mathrm{Mg}$ supplementation on Fe status parameters (serum $\mathrm{Fe}, \mathrm{H} H \mathrm{gb}$, hematocrit). PCA analysis revealed a positive correlation between serum $\mathrm{Fe}$ and SAT after 11 days of supplementation. Reddy et al. have explained similiar associations in $\mathrm{Fe}$ status parameters but in patients with functional anemia in chronic kidney disease (37). Anemia could be present as a latent condition, mostly in young women who are in the reproductive period. In order to optimize $\mathrm{Fe}$ status it is important to monitor biochemical parameters and routinely examine relevant markers (38).

Previously published data suggest an interaction between the resorption of divalent cations such as $\mathrm{Mg}$ and Fe. Namely, the deficiency of one divalent cation in the intestine can lead to increased resorption of other divalent cations (39). In an animal model, it has been shown that Fe deficiency can lead to increase in intestinal absorption of $\mathrm{Mg}$, calcium and phosphorus since the same receptor may be involved in the resorption of these chemically similar cations (40). Low dietary intake of $\mathrm{Mg}$ in rats has been shown to increase Fe resorption (41). Furthermore, in vitro studies have demonstrated that $\mathrm{Mg}$ salts can negatively affect absorption of $\mathrm{Fe}$ by raising the $\mathrm{pH}$ value as the availability of Fe salts in the intestinal tract is $\mathrm{pH}$ dependent (42). Moreover, certain $\mathrm{Mg}$ salts can absorb Fe and thus interact with its absorption (42).

On the contrary, there are studies linking $\mathrm{Mg}$ intake and the risk of developing anemia $(15,16,42-$ 44). In our study, we have demonstrated that short term supplementation with $\mathrm{Mg}$ and increased level of serum $\mathrm{tMg}$ and $\mathrm{iMg}$ could have benefical effects on \% SAT and serum Fe. Magnesium is a cofactor of a large number of enzymes, with an important role in the synthesis of hemoglobin. Accordingly, Mg deficiency can interrupt hemoglobin synthesis and erythrocyte energy metabolism and result in anemia. In addition, $\mathrm{Mg}$ deficiency has been reported to be associated with an inflammatory process, which could lead to anemia (45). Therefore, the question arises as to whether $\mathrm{Mg}$ supplementation is required in persons who are not deficient in this trace element, and leaves space to the future studies to examine longitudinal effects of $\mathrm{Mg}$ supplementation on Fe status indices.

The key limitation of the present study is missing data regarding the leukocyte, thrombocyte, and erythrocyte counts as well as ferritin level, after the inter- 
vention period although changes in these parametres couldn't be expected during short intervention period. Additionally, acknowledge that calculated transferrin concentrations provide limited information. Furthermore, the duration of the $\mathrm{Mg}$ supplementation may have been short to explore the dynamical changes of the supplements' effects on biomarkers of Fe status. Similar studies are of interest in the male population, as well.

\section{Conclusion}

This study results indicate that Mg supplementation leads to an improvement in the certain iron status parameters even in individuals with optimal levels of these indices. Additionally, the analyzed parameters were significantly correlated, and after the intervention period, a significant positive association among

\section{References}

1. Fiorentini D, Cappadone C, Farruggia G, Prata C. Magnesium: biochemistry, nutrition, detection, and social impact of diseases linked to its deficiency. Nutrients 2021; 13: 1136-80.

2. Barbagallo $M$, Veronese $N$, Dominguez $\sqcup$. Magnesium in aging, health and diseases. Nutrients 2021; 13: 46383.

3. Piuri G, Zocchi M, Della Porta M, Ficara V, Manoni M, Zuccotti GV, et al. Magnesium in obesity, metabolic syndrome, and type 2 diabetes. Nutrients 2021; 13: 32036.

4. EFSA Panel on Dietetic Products, Nutrition and Allergies (NDA). Scientific opinion on dietary reference values for magnesium. EFSA Journal 2015; 13: 4186. https://doi.org/10.2903/j.efsa.2015.4186

5. Institute of Medicine (US) Standing Committee on the scientific evaluation of dietary reference intakes. Dietary reference intakes for calcium, phosphorus, magnesium, vitamin $D$, and fluoride. Washington (DC): National Academies Press (US); 1997.

6. Olza J, Aranceta-Bartrina J, González-Gross M, Ortega RM, Serra-Majem L, Varela-Moreiras G, et al. Reported dietary intake, disparity between the reported consumption and the level needed for adequacy and food sources of calcium, phosphorus, magnesium and vitamin $D$ in the Spanish population: findings from the ANIBES study. Nutrients 2017; 9: 168-85.

7. Tarleton EK. Factors influencing magnesium consumption among adults in the United States. Nutrition reviews 2018; 76: 526-38.

8. Mensink GBM, Fletcher R, Gurinovic M, Huybrechts I, Lafay L, Serra-Majem L, et al. Mapping low intake of micronutrients across Europe. British journal of nutrition 2013; 110: 755-73. the analyzed parameters was achieved. However, caution should be exercised when supplementing $\mathrm{Mg}$, and laboratory monitoring of the interaction is required. Further research is warranted regarding the possible impact of the forms of $\mathrm{Mg}$ preparations that exist on the market, and whether they equally affect biochemical changes of iron status in healthy young people as well as in specific target groups of patients.

Acknowledgements. This work was supported by the Ministry of Education, Science and Technological Development of Serbia on the basis of contract No.175036 and No.451-03-68/2020-14/200161.

\section{Conflict of interest statement}

All the authors declare that they have no conflict of interest in this work.

9. Cazzola R, Della Porta M, Manoni M, lotti S, Pinotti L, Maier JA. Going to the roots of reduced magnesium dietary intake: A tradeoff between climate changes and sources. Heliyon 2020; 6: e05390. doi: 10.1016/ j.heliyon.2020.e05390

10. Doyle L, Flynn A, Cashman K. The effect of magnesium supplementation on biochemical markers of bone metabolism or blood pressure in healthy young adult females. Europ J Clin Nutrit 1999; 53: 255-61.

11. Al Alawi AM, Majoni SW, Falhammar H. Magnesium and human health: perspectives and research directions. Int J Endocrin 2018; ID 9041694. https://doi.org/ 10.1155/2018/9041694

12. Gröber U, Schmidt J, Kisters K. Magnesium in prevention and therapy. Nutrients 2015; 7: 8199-226.

13. Dominguez L, Veronese N, Barbagallo M. Magnesium and hypertension in old age. Nutrients 2021; 13: 13971.

14. Dong JY, Xun P, He K, Qin LQ. Magnesium intake and risk of type 2 diabetes meta-analysis of prospective cohort studies. Diabetes Care 2011; 34: 2116-22.

15. Zhan Y, Chen R, Zheng W, Guo C, Lu L, Ji X, et al. Association between serum magnesium and anemia: China health and nutrition survey. Biological trace element research 2014; 159: 39-45.

16. Shi Z, Hu X, He K, Yuan B, Garg M. Joint association of magnesium and iron intake with anemia among Chinese adults. Nutrition 2018; 24: 977-84.

17. Kamiński $M$, Kręgielska-Narożna $M$, Bogdański $P$. Determination of the popularity of dietary supplements using google search rankings. Nutrients 2020; 12 : 908-23.

18. De Franceschi L, Brugnara C, Beuzard Y. Dietary magnesium supplementation ameliorates anemia in a mouse 
model of $\beta$-thalassemia. Blood, The Journal of the American Society of Hematology 1997; 90: 1283-90.

19. De Franceschi L. Oral magnesium pidolate: effects of long term administration in patients with sickle cell disease. British Journal of Haematology 2000; 108: 284-9.

20. Cinar V, Nizamoglu M, Mogulkoc R, Baltaci AK. Effects of magnesium supplementation on blood parameters of athletes at rest and after exercise. Biological trace element research 2007; 115: 205-12.

21. Coad J, Conlon C. Iron deficiency in women: assessment causes and consequences. Curr Opin Clin Nutr Metab Care 2011; 14: 625-34.

22. Le $\mathrm{CH}$. The prevalence of anemia and moderate-severe anemia in the US population (NHANES 2003-2012) PLoS One 2016; 11: e0166635. doi:10.1371/ journal.pone.0166635

23. Nikolić $M$, Milešević J, Zeković $M$, Gurinović $M$, Glibetić $M$. The development and validation of food atlas for portion size estimation in the Balkan region. Front Nutr 2018; 5: 78-86.

24. Gurinović M, Milešević J, Kadvan A, Nikolić M, Zeković $M$, Djekić-lvanković $M$, et al. Development, features and application of Diet Assess and Plan (DAP) software in supporting public health nutrition research in Central Eastern European Countries (CEEC). Food Chem 2018; 238: 186-94.

25. Gurinović $M$, Milešević J, Kadvan A, Djekić-Ivanković $M$, Debeljak-Marta ić J, Takić $M$, et al. Establishment and advances in the online Serbian food and recipe data base harmonized with EuroFIRTM standards. Food Chem 2016; 193: 30-8.

26. European Food Safety Authority (EFSA) Dietary Reference Values for nutrients Summary report. EFSA Support Publ 2017; e15121: 98 pp. https://doi.org/ 10.2903/sp.efsa.2017.e15121

27. Arslan DF, Karakoyun I, Isbilen B, Basok, Aksit ZM, Celik $E$, et al. The effects of education and preanalytical errors. J Med Biochem 2018; 37: 172-80.

28. Worwood M, May AM, Bain BJ. Iron deficiency anaemia and iron overload. In Dacie and Lewis Practical Haematology 11ed; 2017; (Section 9): 165-86.

29. Favus MJ, Bushinsky DA, Lemann Jr J. Regulation of calcium, magnesium, and phosphate metabolism. American Society for Bone and Mineral Research 2006; 13: 76-83.

30. Milman NT. Dietary iron intake in women of reproductive age in Europe: a review of 49 studies from 29 countries in the period 1993-2015. Journal of Nutrition and Metabolism 2019; ID 7631306 . https://doi.org/ $10.1155 / 2019 / 7631306$

31. Samaniego-Vaesken M, Partearroyo T, Olza J, ArancetaBartrina J, Gil Á, González-Gross M, et al. Iron intake and dietary sources in the Spanish population: findings from the ANIBES study. Nutrients 2017; 9: 203-17.
32. Finch CA, Deubelbeiss K, Cook JD, Eschbach JW, Harker LA, Funk DD, et al. Ferrokinetics in man. Medicine (Baltimore). 1970; 49: 17-53.

33. Nelson M, Erens B, Bates B, Church S, Boshier T. Low Income Diet and Nutrition Survey. Food consumption and nutrient intake. London: TSO, 2007a; 2: 34-7.

34. Nelson M, Erens B, Bates B, Church S, Boshier T. Low Income Diet and Nutrition Survey. Nutrition status, physical activity and economic, social and other factors. London: TSO, 2007b; 3: 38-43.

35. Welch $A A$, Fransen $H$, Jenab $M$, Boutron-Ruault MC, Tumino R, Agnoli Cet al. Variation in intakes of calcium, phosphorus, magnesium, iron and potassium in 10 countries in the European Prospective Investigation into Cancer and Nutrition study. European Journal of Clinical Nutrition 2009; 63: 101-21.

36. Solovyova VA, Gace V, Ermolenko KS, Khorolskiy VA. Anemia in women of reproductive age. Intech Open 2018; (Chapter 5): 91-103.

37. Reddy GC, Devaki R, Rao P. Iron indeces in patients with functional anemia in chronic kidney disease. JIFCC 2013; 24: 129-36.

38. Kılıç M, Özpınar A, Serteser A, Kilercik M, Serdar M. The effect of reticulocyte hemoglobin content on the diagnosis of iron deficiency anemia: a meta analysis study. J Med Biochem 2022; 41: 19-31.

39. Hill CH, Gennard M. Chemical parameters in the study of in vivo and in vitro interactions of transition elements. Fed Proc 1970; 29: 1474-81.

40. Campos MS, Barrionuevo M, Alférez MJM, Gómez-Ayala $A \hat{E}$, Rodriguez-Matas MC, Lopezêaliaga l, et al. Interactions among iron, calcium, phosphorus and magnesium in the nutritionally iron-deficient rat. Experimental Physiology 1998; 83: 771-81.

41. Sanchez-Morito N, Planells E, Aranda P, Llopis J. Influence of magnesium deficiency on the bioavailability and tissue distribution of iron in the rat. J Nutr Biochem 2000; 11: 103-8.

42. Disch G, Classen HG, Haubold W, Spätling L. Interactions between magnesium and iron. In vitro studies. Arzneimittel-forschung 1994; 44: 647-50.

43. Xu X, Hall J, Byles J, Shi Z. Dietary pattern, serum magnesium, ferritin, $\mathrm{C}$-reactive protein and anaemia among older people. Clinical Nutrition 2017; 36: 444-51.

44. Biyik Z, Yavuz YC, Altintepe L. Association between serum magnesium and anemia in patients with chronic kidney disease. International Urology and Nephrology 2020; 52: 1935-41.

45. Guerrero-Romero F, Bermudez-Peña C, RodríguezMorán M. Severe hypomagnesemia and low-grade inflammation in metabolic syndrome. Magnesium Research 2011; 24: 45-53. 